\title{
POLA KEPEMIMPINAN LAKI-LAKI DAN PEREMPUAN DALAM RUANG LIINGKUP GEREJA
}

\section{milgasrial@gmail.com}

Abstrac

Abstrac

Artikel ini membahas tentang sistem kepemimpinan antara laki laki dan perempuan dalam suatu komunitas Gereja. Metode yang digunakan adalah metode deskriptif. Tujuan dari penelitian ini adalah untuk mengetahui sampai dimana kekuatan Gereja dalam menerima seorang pemimpin yang tidak di lihat dari Gender-nya.Penelitian ini memperlihatkan atau menunjukkan bahwa kepemimpinan dalam suatu lembaga gereja itu sangat penting untuk membina persekutuan dan tanpa membedakan seorang pemimpin untuk memimpin jemaat ke arah yang lebih baik, sehingga tidak mudah di goyahkan oleh perkembangan yang bersifat negatife yang dapat menimbulkan perpecahan dalam Gereja.

Kata Kunci: Laki-laki,Perempuan,Gereja,kepemimpinan.

PENDAHULUAN

Bercermin dari Tokoh-tokoh Perjanjian Lama yaitu Ezra dan Nehemia yang mengambil peranan penting dalam membawa kembali Bangsa Israel dari pembuangan, di sini kita mencoba mengaitkan bagaimana pola kepemimpinan antara laki-laki dan perempuan. Dari tokoh di atas ketika kita lebih berfokus kepada Ezra, maka Ezra-lah yang lebih banyak membawa orang-orang Israel dari pembuangan di bandingkan dengan Nehemia. Disini bukan kita melihat kuantitas orang orang buangan tetapi ini membuktikan bahwa kepemimpinan perempuan juga jangan di anggap lemah, karena terbukti bahwa Ezra lebih mampu membawa dua kelompok orang Israel dari tempat buangan. ${ }^{1}$ Dalam Alkitab terlihat bahwa posisi laki -laki lebih dominan dibanding perempuan. Kendati demikian dalam beberapa kasus, peranan perempuan tidak kalah penting dari laki-laki. Tokoh tokoh perempuan antara

\footnotetext{
${ }^{1}$ Rannu Sanderan, "JABATAN GEREJAWI DAN PERAN PEREMPUAN DALAM PELAYANAN GEREJA". Pracetak OSF, 26 November 2021. Terakhir diubah 26 November 2021. Osf.io/jtcag.
} 
lain: Ester,Rut,Debora,Rahab,Maria,Lidya,dan lain sebagainya. Secara umum, pandangan orang terhadap kepemimpinan perempuan memang tidak sebanding dengan power yang dimiliki laki-laki. Dari artikel ini akan kita tunjukkan bahwa perempuan bisa menandingi kekuatan laki-laki dalam memimpin atau sebagai pelayan dalam ruang lingkup Gereja.

\section{TUJUAN DAN MANFAAT}

Tujuan dari Topik ini adalah, bukan kita mencari titik kelemahan seorang pemimpin, namun bertujuan untuk bagaimana Suatu Gereja menerima latar belakang, terlebih Gender-nya seorang pemimpin dalam ruang pelayanan Gereja, untuk membina dan mengembangkan suatu Gereja ke arah yang lebih di harapkan Tuhan atas persekutuan tersebut.

Manfaat untuk mengetahui bagaimana cara pandang kita terhadap seorang pemimpin sangat penting, untuk menerima segala kekurangan dan kelemahan dalam menjalankan suatu persekutuan dan terlebih kita mampu saling memahami dengan segala kekurangan yang dimiliki manusia secara umum, khususnya kepemimpinan seorang perempuan.

\section{PEMBAHASAN}

\section{KEPEMIMPINAN LAKI-LAKI DAN KEPEMIMPINAN PEREMPUAN}

Kedudukan laki-laki dan perempuan secara umum, memang berbeda. Perbedaan tersebut terlihat jelas dari tanggungjawab masing masing pihak. Laki-laki mempunyai tanggungjawab yang banyak namun bukan berarti perempuan tidak punya tanggungjawab, dalam arti bahwa tanggungjawab seorang perempuan tidak kala banyak dari seorang laki-laki. Dalam kitab Kejadian 3:16-17 disitu jelas tanggung jawab Laki-llaki dan perempuan dipisahkan. Laki-laki akan mencari nafkah dan perempuan akan bersusah paya melahrikan dan akan mengurus anak-ankn-nya dan mengurus suaminya dan suami akan berkuasa atas Perempuan ini. Tanggung jawab ini dipisahkan bukan berarti bahwa mereka akan menjalankan tugas mereka masingmasing, tetapi ada hal-hal yang penting yang perlu di perhatikan dalam menjalankan tanggung jawab nya. 
Untuk menjadi seorang pemimpin dibutuhkan beberapa hal untuk menunjang keberhasilan dalam memimpin suatu komunitas, contohnya komunitas Gereja. Peran pemimpin untuk mempengaruhi orang orang yang dipimpin ke arah yang baik khususnya pemimpin dari keagaaman sangatlah penting, karena jabatan seorang pemimpin menentukan maju tidaknya sebuah komunitas yang di pimpinnya. ${ }^{2}$ Intuisi atau Gagasan seseorang memepengaruhi dalam membentuk orientasi terhadap sesama manusia dan akhirnya juga turut berperan dalam berbagai tindakan religious dan pertimbangan serta pemgambilan keputusan etis.

Secara umum laki-laki dan perempuan sebenarnya tidak memiliki perbedaan yang menonjol dalam memimpin. Issu-issu yang sering kita dengar bahwa memang lakilaki dalam kepemimpinannya sedikit lebih tegas daripada perempuan. Namun disini jangan kita kaitkan dengan karakter yang nyatanya sangat menjolok jika kita perbandingkan, Tetapi hendaknya kita bandingkan seberapa besar dan pintarnya juga kreatifnya atau scill seseorang dalam memimpin suatu kelompok atau komunitas. Di Negara Indonesia secara umum, justru perempuan lah yang lebih menampakkan kepemimpinan seorang pemimpin yang begitu hebat.

\section{PEMIMPIN LAKI-LAKI DAN PEREMPUAN KHUSUS DALAM GEREJA}

Lembaga Gereja adalah sebuah lembaga yang berdiri atas adanya Agama keKristenan. Tanpa Kristen maka Gereja tidak akan ada. Dalam Gereja sendiri memiliki sistem atau cara cara untuk membentuk sebuah Jemaat, dan Jemaat itu terbentuk karena struktur kepemimpinannya tersusun sebagaimana layaknya. Kepemimpinan dalam Gereja tentu bukanlah hal yang bisa kita kaitkan dengan kepemimpinan secara umum, Tetapi kepemimpinan dalam Gereja ada karena inisiatif individu untuk melayani Tuhan yang dia sembah. Beda dengan kepemimpinan Politik misalnya. Dalam Gereja tentu punya pemimpin yang berbeda beda khususnya berbeda Gender. Perbedaan Gender ini-lah yang sering kita sangkut-pautkan dengan kepemimmpinan secara umum. Sebab ajaran dalam Gereja atau Kekristenan tidak pernah mengajarkan perbedaan antara laki-laki dan perempuan. Cuma sedikit disinggung

\footnotetext{
${ }^{2}$ Rannu Sanderan. "INTUISI: Pendalaman Gagasan Hans-George Gadamer Tentang Intuisi Sebagai Supralogika". Jurnal IImiah Religiosity Entity Humanity (JIREH) 2,no.2 (December 23,2020): 114-125. Acessed December 5,2021.
} 
dalam kisah penciptaan bahwa laki-laki dan perempuan memiliki tanggung jawab yang berbeda. Jadi Gereja tidak memandang Gender untuk jadi seorang pendeta. Artinya bahwa pelayan Gereja bukan seperti pelayan di lembaga Sosial yang harus memenuhi syarat-syarat untuk jadi seorang pemimpin. Bertolak dari kisah Yesus yang memilih rasul-rasul, yang dimana latar belakang mereka berbeda beda, disini kita mencoba mengambl titik temu bahwa dalam gereja tidak ada batasan untuk jadi seorang pemimmpin. Tergantung dari diri kita masing masing apakah kita siap untuk memberikan kehidupan kita untuk melayan Tuhan dalam Gereja.

\section{PEMIMPIN GEREJA MASA KINI}

Pemimpin dalam gereja masa kini memang lebih didominasi oleh kaum lakilaki, dan memang bahwa sejak dari dulu laki-laki lebih banyak dipegang oleh laki-laki daripada perempuan. Jika kita melihat gereja masa kini ada gereja yang juga memiliki pemimpin perempuan yang banyak, Khususnya dalam beberapa kepengurusan organisasi intra gereja (OIG). Dalam perannya sebagai pemimpin, Perempuan sekarang ini lebih banyak memilih memimmpin komunitas yang beranggotakan sedikit daripada beranggotakan banyak. Jika kita teliti baik-baik maka suatu lembaga atau organisasi yang dipimpin oleh perempuan, juga tidak tertinggal jauh dari kepemimpinan suatu kelompok yang dipimpin oleh laki-laki. Bahkan, Komunitas perempuan lebih banyak tingkat keberhasilannya dalam mempimpin dari pada laki-laki. Hal ini menunjukkan bahwa Pemimpin sekarang ini dalam bidang Gereja tidak didominasi oleh kaum laki-laki.

\section{KESETARAAN GENDER DALAM MEMIMPIN}

Perbedaan Gender dalam lingkup gereja bukan menjadi suatu persoalan yang terlalu menonjol. Namun dibalik itu ada juga Dedominasi gereja yang menjadikan perbedaan Gender itu merupakan masalah yang tidak bisa diubah karena sesuai dengan Doktrin mereka masing masing. Namun ketika kita melihat secara umum bahwa kesetaraan Gender dalam gereja tidak menjadi penghalang untuk menjadi seorang pemimpin. Khususnya Gereja aliran Calvinis. Dalam gereja secara umum, siapapun yang menjadi pemimpin tidak jadi masalah, karena ajarannya tidak melihat dari pemimpin,namun dilihat dari isi kepemimpinannya itu. Gereja modern memandang bahwa ajaran yang di ajarkan itu-lah yang menjadi prioritas utama 
dalam menjalankan tugas dan tanggung jawab dalam Gerejanya. Dan terlebih jika pemimpinnya itu lebih kreatif dan berkualitas dalam mengarahkan dan membimbing anggota gerejanya.

\section{KESIMPULAN DAN SARAN}

${ }^{3}$ Tugas dan tanggung jawab orang Kristen ialah mulai dengan sikap baru. Sudah waktunya setiap pemimpin memberi perhatian proporsional serta perlakuan yang setara dan adil, entah perempuan atau laki-laki. Peran dari setiap pemimpin dalam gereja sangat memberikan sumbangsi yang baik untuk pertumbuhan rohani anggota gereja-nya. Sumbangsi yang dimaksudkan adalah bagaimana setiap pemimpin memberikan tanggapan dan pemahaman tentang macam-macam karakter seorang pemimpin, dan menyadarkan setiap gereja bahwa kualitas seorang pemimpin tidak-lah selamanya diukur dari Gender sorang pemimpin.

Saran penulis untuk mencapai beberapa tujuan artikel ini adalah mengenali apa itu kepemimpinan sehingga setiap orang memahami dan mengerti bagaimana hendaknya seseorang itu memiliki fungsi sebagai pemimpin dan yang dipimpin.

\footnotetext{
${ }^{3}$ Rannu Sanderan, “JABATAN GEREJAWI DAN PERAN PEREMPUAN DALAM PELAYANAN GEREJA". Pracetak OSF, 26 November 2021. Terakhir diubah 26 November 2021. Osf.io/jtcag.
} 